KAPL-1826

AEC Research and Development Report UC-25, Metals and Ceramics (TID-1500, 13th Edition)

Knolls

Atomic Power

Laboratory

\section{Operated for the}

United States Atomic

Energy Commission by

GENERAL (
C. F. Barrett, Jr.

June 28, 1957 


\section{DISCLAIMER}

This report was prepared as an account of work sponsored by an agency of the United States Government. Neither the United States Government nor any agency Thereof, nor any of their employees, makes any warranty, express or implied, or assumes any legal liability or responsibility for the accuracy, completeness, or usefulness of any information, apparatus, product, or process disclosed, or represents that its use would not infringe privately owned rights. Reference herein to any specific commercial product, process, or service by trade name, trademark, manufacturer, or otherwise does not necessarily constitute or imply its endorsement, recommendation, or favoring by the United States Government or any agency thereof. The views and opinions of authors expressed herein do not necessarily state or reflect those of the United States Government or any agency thereof. 


\section{DISCLAIMER}

Portions of this document may be illegible in electronic image products. Images are produced from the best available original document. 


\section{UNCLLSSIFIED}

KAPI- $1: 826$

UC-25, Metaliurgy and Ceramics:

(TID-4500, 13th ed)

Ceneral Electric Company

KNOLLS ATOMIC POWER LEBORATORY

$\because \ldots$ Schenectady, New York

$\therefore:$

GRISCOM-RUSSELI TWO-TUBE EVAPORATOR

c. F. Barrett, Jr.

June 28, 1957

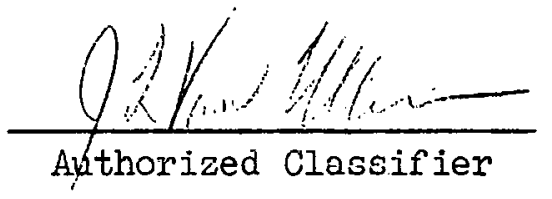

$\frac{2.41 / 457}{\text { Date }}$

Operated for the

United States Atomic Energy Commission

by the

Ceneral Electric Company.

Contract No. W-3I-I09 Eng-52 


\section{LEGAII NOTICE}

This report was prepared as an account of Government sponsored work. Neither the United States, nor the Comission, nor any person acting on behalf of the Commission:

A. Makes any warranty or representation, express or implied, with respect to the accuracy, completeness, or usefulness of the information contained in this report, or that the use of any information, apparatus, method, or process disclosed in this report may not infringe privately owned rights; or

B. Assumes any liabilities with respect to the use of, ox for damages resulting from the use of any information, apparatus, method, or process disclosed in this report.

As used in the above, "person acting on behalf of the Commisolon" includes any employee or contractor of the Comntssion to the extent that such employee or contractor prepares, handles or distributes, or provides access to, any information pursuant to his employment or contract with the Commission. 
KAPL-1826

$\frac{\text { UC-25, Metallurgy and Ceramics }}{(\text { TID-4500, 13th ed })}$

Internal Distribution

No. of Copies

AEC, Schenectady Operations Office $\quad \therefore \quad I$

Anderson, JD

1

Barrett, $\mathrm{CF}, \mathrm{Jr}$.

1

Bedford, AW, Jr.

1

Cashman, . TJ

1

Document Library

4

Doonan, AN

Galonian; GE

Kesselring; $\mathrm{KA}$

Kukfa, RS

Oberly, WN

Stewart, : $\mathrm{EY}$

SIG/S2G File

Van UIlen, Ji

1

1

1

1

1

1

1

1

External Distribution

Aberdeen Proving Ground $\quad \therefore \ldots$

Alco Products, Inc. : : . . 1

Argonne National Laboratory 10

Armed Services Technical Intormation Agency, Daytun ' 5

Atomic Energy Commission, Patent Branch 1

Atomic Energy Commission, Technical Library. 3

Atomics International 2

Babcock \& Wilcox Company 4

Battelle Memorial Institute 2

Bettis Plant 4

Boeing Airplane Company 1

Brookhaven National Laboratory 2

Brush Beryllium Company 1

Bureau of Ships (Code 1500) 1

Chicago Patent Group 1

Columbia University (Dr. Hassialis) 1

Combustion Ingineering, Inc. 1

Consoliaatea Tultee Aircraft Corporation . ' 2

Convair-General Dynamics . 1

Defence Research Member 1

Department of Food Technology (MIT) 1 
KAPL-1826

External Distribution (continued)

№. of Copies

Department of Navy (Code 422)

1

Department of the Army, G-2

Division of Raw Materials, Denver

Dow Chemical Company, Pittsburg

Dow Chemical Company (Rocky Flats)

Du Pont de Nemours and Company, Aiken

Du Pont de Nemours and Company, Wilmington

Frankford Arsenal.

General Electric Company (ANPP)

General Electric Company, Richland

Veneral Nuclear Engineering Corporation

Goodyear Atomic Corporation

Iowa State College

Kirtland Air Force Base

Lockheed Aircraft Corporation (Bauer)

Los Alamos Scientific Laboratory

Mallinckrodt Chemical Works

Mound Laboratory

National Advisory.Comnittee for Aeronautics, Cleveland

National Bureau of Standards, Atomic Energy Project.

National Bureau of Standards (Jibrary)

National Lead Company, Inc., Winchester.

National Lead Company of Ohio

Naval Research Laboratory

New Brunswick Area Office

New York Operations Office

Nuclear Development Corporation of America

Nuclear Metals, Inc.

Oak Ridge Institute of Nuclear Studies

Oak Ridge National Laboratory

Office of Naval Research

Phillips Petroleum Company

RAND Corporation

Sandia Corporation

Signal Corps Center

Sylvania Electric Products, Inc. 1

Technical Research Group 1

Tennessee Valley Authority 1 
KAPL-1826

External Distribution (continued)

№. of Copies

The Martin Company :

1

Union Carbide Nuclear Company (C-31 Plant)

1

Union Carbide Nuclear Company (ORGDP)

United Aircraft Corporation

U.S. Ceological Survey, Denver

U.S. Geological Survey, Menlo Park

U.S. Geological Survey, Washington

U.S. Naval Postgraduate School

U.S. Patent Office

University of. California Radiation Laboratory, Berkeley

University of California Radiation Laboratory, Livermore

Vitro Engineering Division

Watertown Arsenal

Weil, Dr. George L.

Westinghouse Electric Corporation

Technical Information Service Extension, Oak Ridge

Office of Technical Services, Washington 
THIS PAGE

WAS INTENTIONALLY

LEFT BLANK 
KAPL-1826

CONTENTS

Page

\begin{abstract}
• • • •
INTRODUCTION

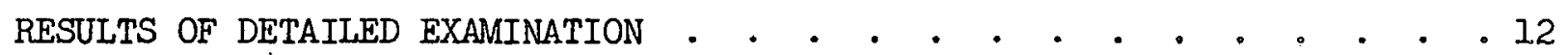

CONCLUSIONS • • • • • • • • • • • • • • • • • • • • •

REFERENCE • • • • • • • • • • • • • • • • • • • • 017
\end{abstract}

\title{
ILLUSTRATIONS
}

№.

Title

1. Typical Cross Section through Tube Showing Both Inner and Outer Tubes (KS-17886) . . . . . . . . . . . 13

2 Enlarged View of Outer Tube Showing Slight Decarburization at Outer Face (KS-17887) • . • . . . . • . . . . 14

3 Enlarged View of Inner Tube Showing Slight Decarburization at Outer Face $(K S-17888)$. . . . . . . . . . 15

4 Microstructure of Welds and Crevices (KS-17889) . . . . . . 16 
THIS PAGE

\section{WAS INTENTIONALLY LEFT BLANK}




\section{ABSTRACT}

This report presents the results of the metallographic examination of the Griscom-Russell two-tube evaporator after testing for a total steaming time of $3856 \mathrm{hr}$. The complete absence of any adverse effect on the material leads to the conclusion that $2-1 / 4 \% \mathrm{Cr}-1 \%$ Mo alloy steel can be used advantageously in liquid metal heat exchangers when the oxygen content of the boiler water is controlled. 
THIS PAGE

WAS INTENTIONALLY

LEFT BLANK 
GRISCOM-RUSSELL TWO-TUBE - EVAPORATOR:

C. F. Barrett, Jr.

\section{INTRODUCTION}

This report presents the results of the metallographic examination of the: Griscom-Russell two-tube evaporator after testing; for a total steaming time: of ${ }^{2}$ $3856 \mathrm{hr}$ at the Mine Safety Appliances: Company; Callery; Pennsylvania:

The evaporator had several unique features with respect to other types: of liquid metal heat exchangers.

-1. The material used for tubes and tube sheet was: $2-1 / 4 \%$ Gr $-1 \%$ Mo:

$\therefore \therefore$ steel rather than the customary austenitic stainless: steeli.

. 2.: :The tubes were expanded after assembly; to provide an intimaite: contact between the outer surface of: the inner tube: and the inner surface of the outer tube for most effective: heat transfer.

3. The inner tube was grooved: on the outer face: to provide: space: for the gas used as the "third fluid" for leak detection.

The design was designated by Griscom-Russell. as the "Bentubell designi: Both: inner and outer tubes were attached at the tube sheet by a seal weld on the outer face and by rolling the tube: into the tube sheet: in accordance: with: standard: commercial practice. The 2-1/4\% chromium - I\% molybdenum steell tubes were both in the annealed condition in this evaporator. The oxygen content of" the water was controlled by the use of sulfite ranging firom lif: to 60 ppm. The: boiler water specification, shown in Table 1, did not specify; sulfite content; but this was added by MSA to ensure: an excess: of sulfite and maintain firee: oxygen within specification.

\begin{tabular}{|c|c|}
\hline $\mathrm{pH}$ & 10.6 to $11: .2$ \\
\hline $\mathrm{PO}_{4} ; \mathrm{ppm}$ & 50: to: 300 \\
\hline Hardness, ppm $\mathrm{CaCO}_{3}$ & $<10$ \\
\hline Oxygen, ppm & $<0.005$ \\
\hline Chlorine, ppm & $<0.1$ \\
\hline Total solids, ppm. & $<1000$ \\
\hline
\end{tabular}


Steam was generated at 500 psig with $\mathrm{NaK}$ at an inlet.temperature of $850^{\circ} \mathrm{F}$ as the primary fluid. Nitrogen and helium were used at different times as the third fluid gas.

\section{RESULTS OF DETAILED EXAMINATION}

The evaporator was cut open longitudinally in such a manner as to leave. one tube in each half. Examination of the tubes, tube sheets, and shell showed ali to be in excellent condition with no evidence of pitting or other corrosion attack. Some loose scale was observed at the inlet end. Scattered rust spots were also noted.

One half was cut longitudinally through the tube sheet at the tube, and the tube was cross sectioned at six locations along the length. None of the sections examined showed any evidence of corrosive attark either of a goncral näture or by pitting. This includes both the surfaces exposed to the NaK and to the boiler water.

Figures 1, 2, and 3 are photomicrographs of the entire cross section at $50 \mathrm{X}$ magnification and of the inner and outer tube at 100X magnification from a typical tube cross section. Figure 4 shows the microstructure of the seal welds and the crevices between the tube and tube sheet.

Measurements of the annulus between the inner and outer tubes on the land between the grooves are shown in lable 2. Two readings $180 \mathrm{deg}$ apart are shown for each cross section.

\section{TABLE 2. Annulus Measurements}

\begin{tabular}{|c|c|c|}
\hline Sample No. & \multicolumn{2}{|c|}{ Width of Annulus, in. } \\
\hline 1 & 0.00016 & 0.00029 \\
\hline 2 & $\therefore 0.00010$ & 0.00026 \\
\hline 3 & 0.00020 & 0.00036 \\
\hline 4 & 0.00029 & 0.00020 \\
\hline 5 & 0.00013 & 0.00033 \\
\hline 6 & 0.00029 & 0.0002 \\
\hline
\end{tabular}




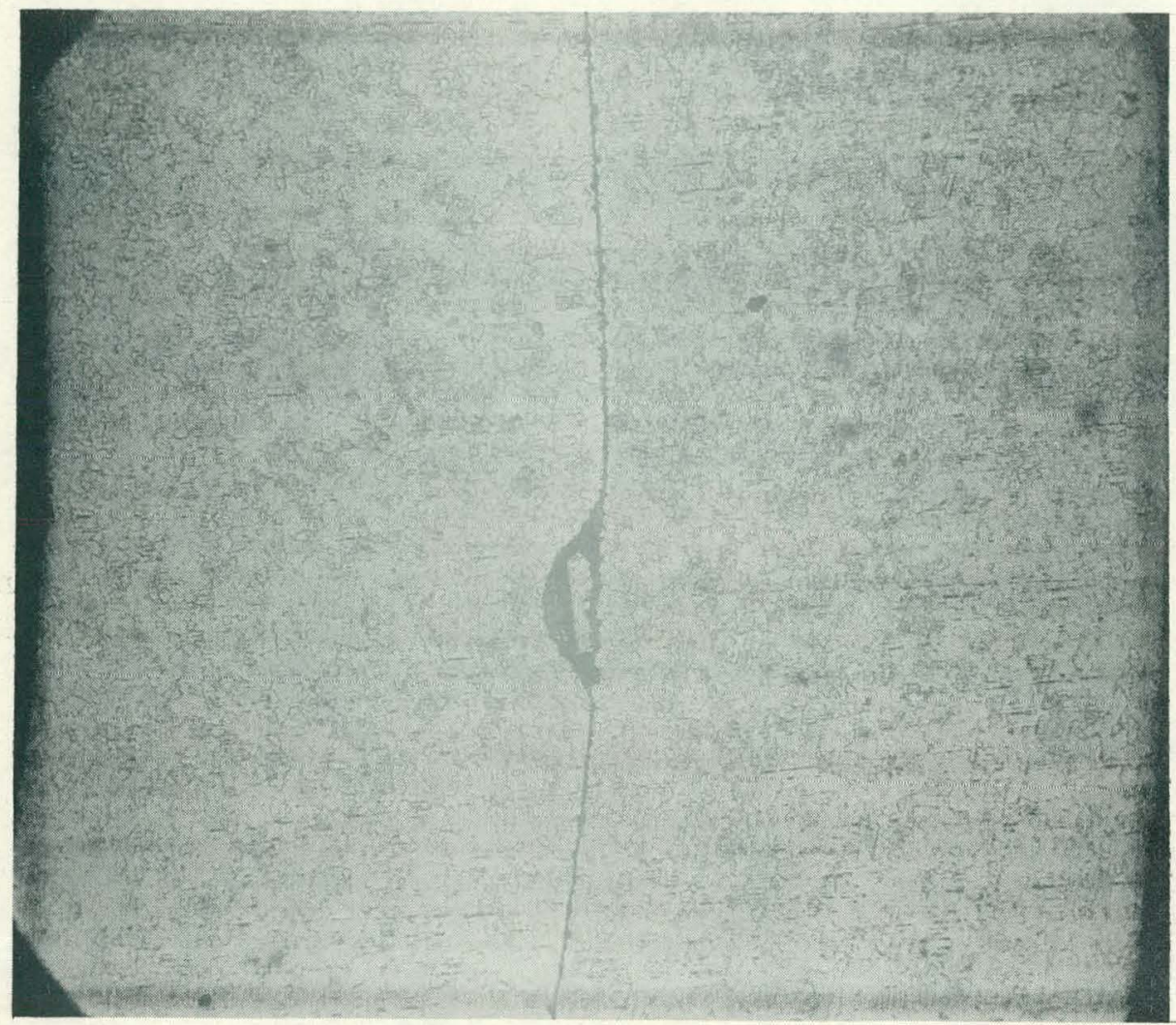

FIGURE 1 TYPICAL CROSS SECTION THROUGH TUBE SHOWING BOTH INNER AND OUTER TUBES thenent 


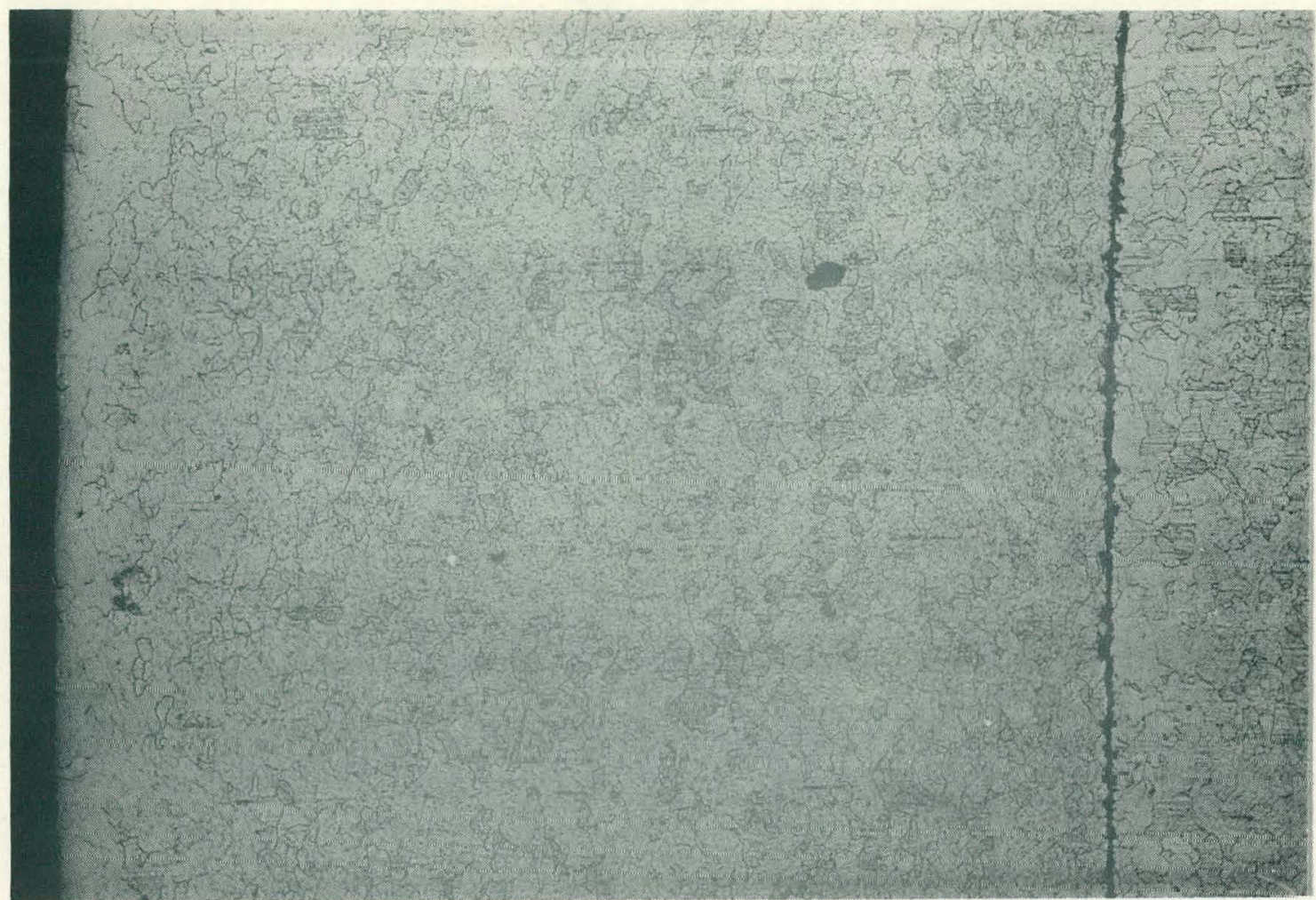

\section{FIGURE 2 ENLARGED VIEW OF OUTER TUBE SHOWING SLIGHT DECARBURIZATION AT OUTER FACE \\ $100 x$}

Note lack of pitting on outer face exposed to boiler water 


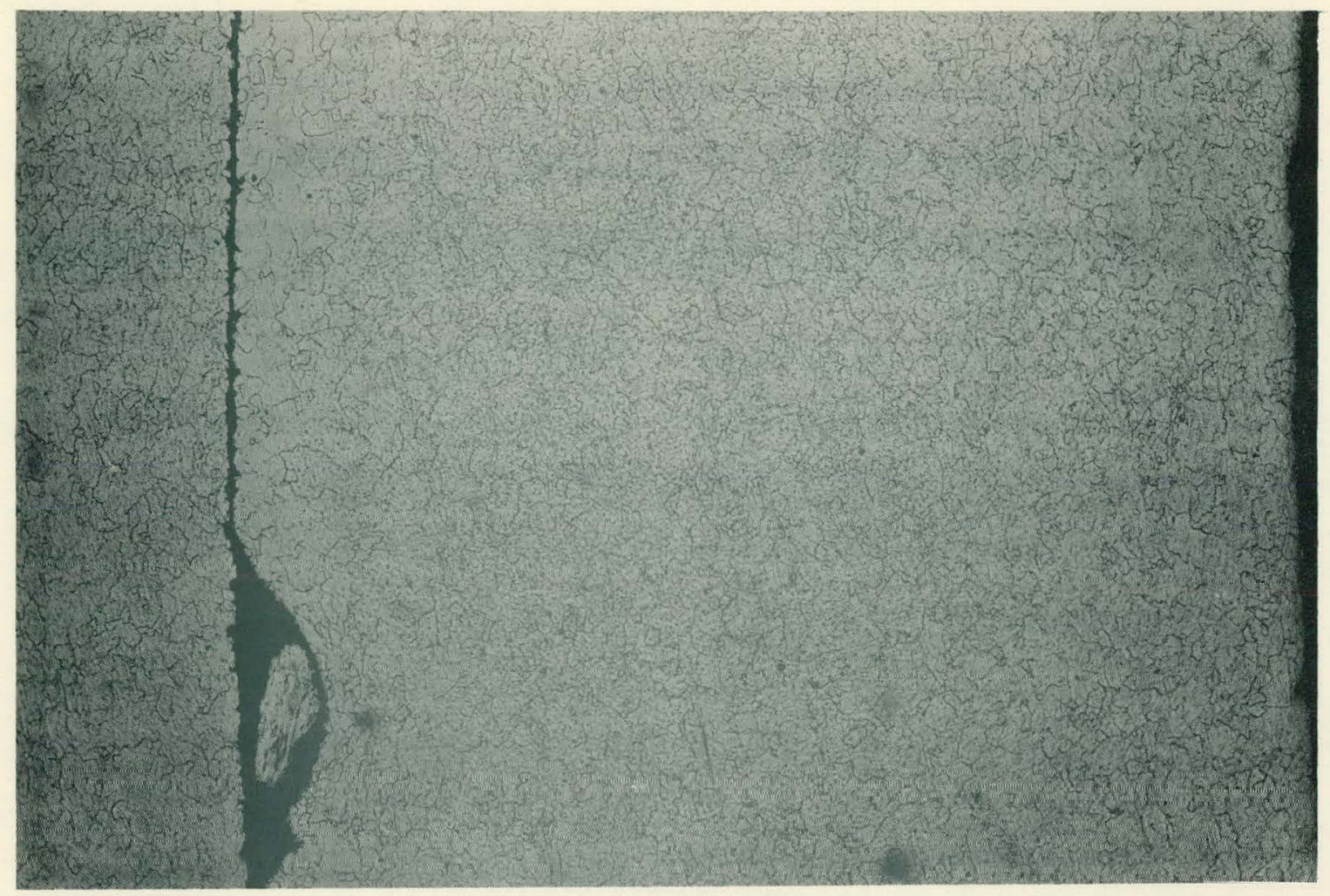

FIGURE 3 ENLARGED VIEW OF INNER TUBE SHOWTNG SLIGHT
DECARBURTZATION AT OUTER FACE
$100 \mathrm{x}$

Note absence of attack on inner face exposed to the NaK 


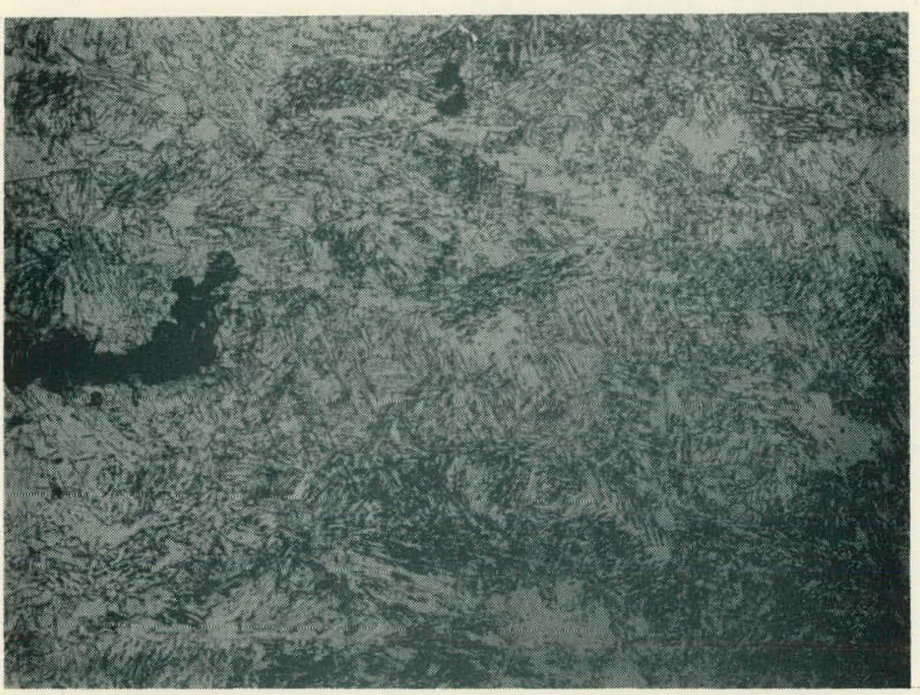

Typical structure of seal weld at tube joint

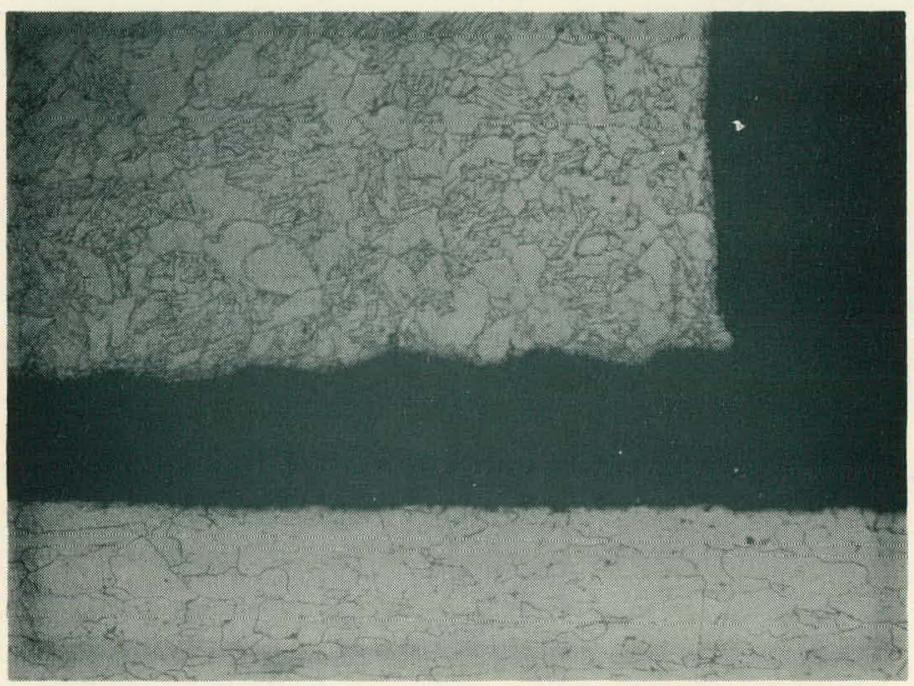

Typical structure of tube - tubesheet crevice area at tube sheet surface exposed to boiler water or $\mathrm{NaK}$

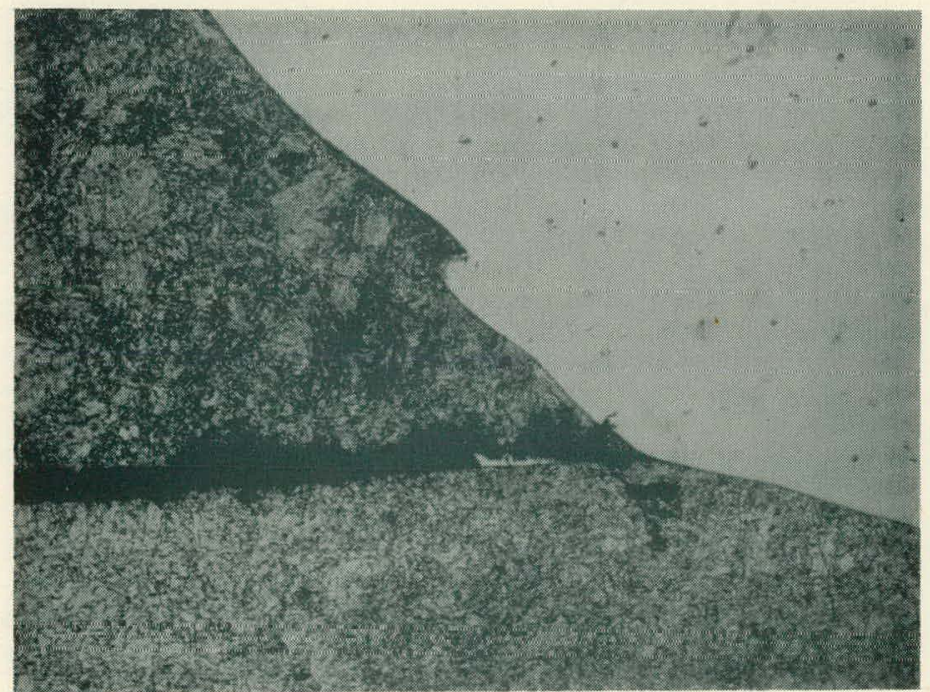

Typical structure of repair weld using Inco Rod " $\mathrm{A}$ " when inner tubes were re-tubed 
The sample designated No. I in Table 2 was located nearest the inlet end, No. 6 was nearest the outlet end, and the others were approximately equidistant between. No distinct trend can be determined from these data except, possibly, that the outlet end tends to have a somewhat wider annulus than the inlet end.

\section{CONCLUSIONS}

The complete absence of any adverse effect on this material during these tests leads to the conclusion that the 2-1/4\% $\mathrm{Cr}-1 \%$ Mo steel can be used advantageously in liquid metal heat exchangers when the oxygen content of the boiler water is controlled.

Design advantages include the higher heat conductivity of the ferritic material and a lower thermal coefficient of expansion with resulting lower stresses, in addition to a lower material cost and freedom from susceptibility to chloride stress corrosion.

\section{REFERENCE}

MSA Technical Report 51, "Two-Tube Steam Evaporator No. 3," W. Milich E. A. Schultz, and E. C. King, November 26, 1956. 